\title{
Zone zero thoracic endovascular aortic repair is all about "location, location, location"
}

\author{
Kevin L. Greason, MD
}

From the Department of Cardiovascular Surgery, Mayo Clinic, Rochester, Minn

Disclosures: Author has nothing to disclose with regard to commercial support.

Received for publication Dec 5, 2017; accepted for publication Dec 18, 2017; available ahead of print Jan 31, 2018

Address for reprints: Kevin L. Greason, MD, Department of Cardiovascular Surgery, Mayo Clinic, 200 First St, Southwest, Rochester, MN 55905 (E-mail: greason.kevin@mayo.edu).

J Thorac Cardiovasc Surg 2018;155:1358-9

$0022-5223 / \$ 36.00$

Copyright (c) 2017 by The American Association for Thoracic Surgery

https://doi.org/10.1016/j.jtcvs.2017.12.065

Readers of the Journal will find interest in this article by Roselli and colleagues ${ }^{1}$ on a proposed modification to the classification of ascending aortic landing zone zero. Although open surgical repair is a safe option for the majority of patients with disease of the ascending aorta, not all patients are surgical candidates. ${ }^{2}$ In the International Registry of Aortic Dissection, 19\% of patients with acute aortic dissection were classified as inoperable, many because of advanced age or severe comorbid illness. ${ }^{3}$

It seems reasonable to expect success by simply extending the techniques of endovascular repair from the descending thoracic aorta to the ascending aorta. The ascending aorta is quite a different landscape than the descending thoracic aorta, however, one that is challenged by complex pathologic, hemodynamic, and anatomical constraints; furthermore, the ascending thoracic aorta is not straight but curved, with the lesser curve of the aorta being upwards of $3 \mathrm{~cm}$ (ie, $30 \%$ ) shorter than the greater curve. ${ }^{2}$

A key point in the article is that there are no commercially available endovascular grafts designed specifically for the ascending aorta. The only available grafts are straight, and they are not engineered to deal with the complex anatomical challenges of the aortic root. According to the authors, the ideal graft should be highly conformable, curved, exceedingly precise, repositionable, and have adequate strength of fixation, a relatively flush edge, and a short delivery tip. A seemingly simple "form follows function" request but, in reality, a difficult order to fill.

The present article is a summary of the authors' endovascular experience with 39 high-risk patients with disease of the ascending aorta. A previous publication of the first 22 patients explored the feasibility of endovascular intervention in the ascending aorta. ${ }^{4}$ Based on their experience with an additional 17 patients, the authors now propose a modification to the landing zone zero into 3 additional zones: 0A (aortic valve annulus to distal

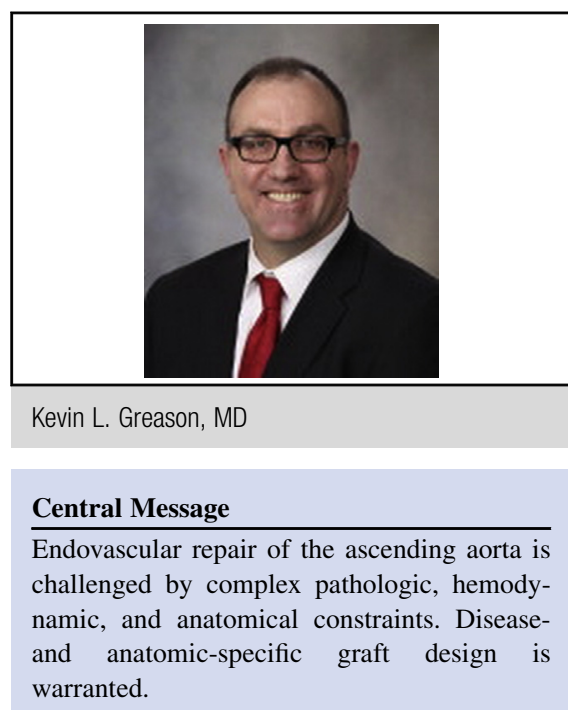

See Article page 1381.

margin of highest coronary artery), $0 \mathrm{~B}$ (from above the coronary to the distal margin of the right pulmonary artery), and 0C (from the right pulmonary artery border to the innominate artery).

The main finding of this study was that zone 0A disease independently predicted mortality (Table 2). The authors question whether the association was a shortcoming of the technology because in 3 of the 5 operative deaths, the proximal landing zone of the graft was in zone $0 \mathrm{~B}$, whereas the proximal extent of disease was zone 0A. Although no specific pathology was associated with mortality, the 5 operative deaths occurred in patients with acute ascending aortic dissection. There were no operative deaths in patients with acute intramural hematoma, pseudoaneurysm, or chronic dissection that did not involve zone 0A.

The main strength of the article is the updated experience in the nascent field of endovascular repair of disease of the ascending aorta. The main weakness is the small sample size. For the moment, when it comes to endovascular repair of ascending aortic disease, surgeons should think "location, location, location."

\section{References}

1. Roselli EE, Idrees JJ, Johnston DR, Eagleton MJ, Desai MY, Svensson LG. Zone zero thoracic endovascular aortic repair: a proposed modification to the classification of landing zones. J Thorac Cardiovasc Surg. 2018;155:1381-9. 
2. Roselli EE, Hasan SM, Idrees JJ, Aftab M, Eagleton MJ, Menon V, et al. Inoperable patients with acute type A dissection: are they candidates for endovascular repair? Interact Cardiovasc Thorac Surg. 2017;25:582-8.

3. Trimarchi S, Neinaber CA, Rampoldi V, Myrmel T, Suzuki T, Mehta RH, et al. Contemporary results in surgery in acute type A aortic dissection: the International
Registry of Acute Aortic Dissection experience. J Thorac Cardiovasc Surg. 2005; 129:112-22.

4. Roselli EE, Idrees J, Greenberg RK, Johnston DR, Lytle BW. Endovascular stent grafting for ascending aorta repair in high-risk patients. J Thorac Cardiovasc Surg. 2015;149:144-54.

Access to The Journal of Thoracic and Cardiovascular Surgery Online is reserved for print subscribers!

Full-text access to The Journal of Thoracic and Cardiovascular Surgery Online is available for all print subscribers. To activate your individual online subscription, please visit The Journal of Thoracic and Cardiovascular Surgery Online, point your browser to http://www.mosby.com/itcvs, follow the prompts to activate your online access, and follow the instructions. To activate your account, you will need your subscriber account number, which you can find on your mailing label (note: the number of digits in your subscriber account number varies from 6 to 10). See the example below in which the subscriber account number has been circled:

\section{Sample mailing label}

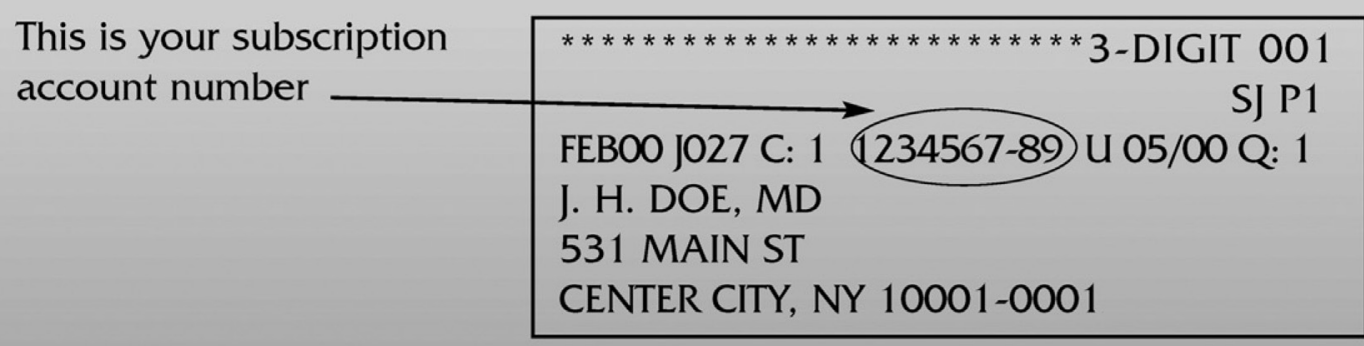

Personal subscriptions to The Journal of Thoracic and Cardiovascular Surgery Online are for individual use only and may not be transferred. Use of The Journal of Thoracic and Cardiovascular Surgery Online is subject to agreement to the terms and conditions as indicated online. 